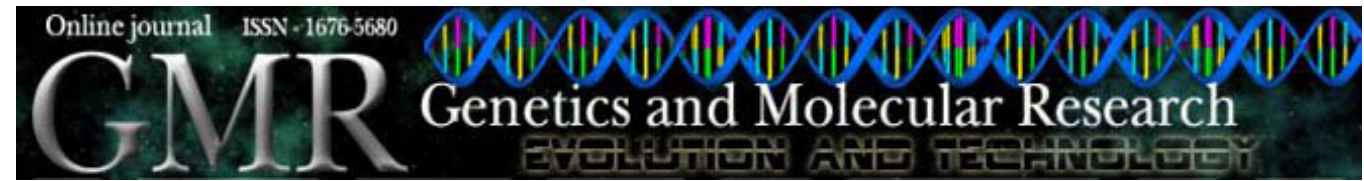

\title{
Genetic diversity in wild species of passion fruit (Passiflora trintae) based on molecular markers
}

\author{
C.B.M. Cerqueira-Silva ${ }^{1,2}$, C.B. Cardoso-Silva ${ }^{2}$, E.S.L. Santos ${ }^{1,2}$, \\ L.D.H.C.S. Conceição ${ }^{3}$, A.S. Pereira ${ }^{4}$, A.C. Oliveira ${ }^{5}$ and R.X. Corrêa ${ }^{4}$
}

${ }^{1}$ Departamento de Estudos Básicos e Instrumentais, Universidade Estadual do Sudoeste da Bahia, Itapetinga, BA, Brasil

${ }^{2}$ Instituto de Biologia, Universidade Estadual de Campinas, Campinas, SP, Brasil

${ }^{3}$ Centro Pesquisa Agropecuária do Cerrado,

Empresa Brasileira de Pesquisa Agropecuária, Planaltina, DF, Brasil

${ }^{4}$ Departamento de Ciências Biológicas, Universidade Estadual de Santa Cruz, Ilhéus, BA, Brasil

${ }^{5}$ Departamento de Ciências Naturais,

Universidade Estadual do Sudoeste da Bahia, Vitória da Conquista, BA, Brasil

Corresponding author: R.X. Corrêa

E-mail: ronanxc@uesc.br

Genet. Mol. Res. 9 (4): 2123-2130 (2010)

Received April 13, 2010

Accepted August 2, 2010

Published October 26, 2010

DOI 10.4238/vol9-4gmr875

\begin{abstract}
In spite of the importance of and the considerable variability observed in Passiflora (Passifloraceae), little is known about the genetic diversity of most of the species of this genus. We evaluated the genetic diversity by RAPD markers in 18 genotypes of Passiflora trintae. The 15 primers generated 112 markers, 84\% of which were polymorphic. The genetic distance estimated by the complement of the Dice index (average dissimilarity $=0.30$ ) and genotype grouping based on the UPGMA algorithm showed low variability among genotypes. More attention should be given to
\end{abstract}


the study and conservation of the biodiversity of this economically important genus.

Key words: Coefficient of similarity; Conservation; Genetic breeding; Genetic variability; Grouping analyses; Molecular marker

\section{INTRODUCTION}

The family Passifloraceae Juss. ex. DC belongs to the order Violales, Class Magnoliopsida and Phylum Magnoliophyta. It originated in tropical America and has approximately 580 species and 18 genera (Bernacci, 2003; Souza and Meletti, 1997). Among these, the genus Passiflora deserves prominence as it consists of a group of at least 400 species (Bernacci, 2003), including P. edulis Sims, which is of greatest economic interest among the Passiflora (Bellon et al., 2007).

In Brazil, the genus Passiflora comprises at least 120 native species spread throughout the country (Bernacci, 2003; Bernacci et al., 2005), and thus, Brazil is considered to be one of the main centers of genetic diversity of the group (Faleiro et al., 2005). However, this diversity, which is of both economic and ecological interest, is being threatened due to the extensive reduction of forest areas, caused by anthropic actions. As an example, we may cite the high rates of deforestation that occur in the tropical regions in general (Bernacci et al., 2005).

Among the tropical regions affected by anthropic actions are the fragments of jungleforest vines, a transition biome between scrub brush areas, arid plains and the Atlantic forest of the city of Vitória da Conquista, in the State of Bahia, Brazil. This biome is also known as the Semidecidual Seasonal Forest of Conquista's plateau. Consequently, the devastation of the native vegetation has accelerated, and the fragmentation of habitats has caused, directly or indirectly, the loss of genetic diversity, through extractivism or environmental changes. According to Queiroz et al. (1992), the loss of the genetic diversity of wild species of the genus Passiflora in the semi-arid regions, among other species of the Brazilian flora, is caused by i) formation of pastures, ii) production of energy from plant biomass to be used in several industries such as commercial bakeries and brick factories, and iii) other types of industrial burnings. Regrettably, actions related to Passiflora preservation, such as the search and maintenance of accessions in germplasm collections and banks, have not received the attention they deserve (Souza and Meletti, 1997).

According to Meletti et al. (2005), several wild species of the genus Passiflora have potential use in breeding programs, considering that these wild species show resistance to pests or diseases, greater longevity, a longer flowering period, adaptation to adverse climactic conditions, and high concentration of chemical components of pharmacological interest, among other potential advantages still unexplored. In relation to the Passiflora species that occur in the jungle-like forest areas of Vitória da Conquista, reported studies are limited to the physical-chemical characterization of fruits of wild genotypes of $P$. setacea (Cardoso-Silva et al., 2007; Cerqueira-Silva et al., 2009a).

In spite of the lack of studies related to the characterization of the Passiflora genus, there is a great number of wild species that recognizably show the genetic variability desired in breeding programs. Associated with the diversity of wild species that form the genus Passiflora, it is the interbreeding possibility among many of these species, and even intraspecific 
crossings, that makes pre-breeding (e.g., search, characterization and germplasm conservation) a rational stage for expansion of the passion fruit crop and conservation of the biodiversity (Faleiro et al., 2005).

In this sense, access to molecular polymorphism at the DNA level optimizes the generation of knowledge useful for conserving the diversity of Passiflora spp, for example, the studies carried out using restriction enzymes of chloroplast DNA sites (Sánchez et al., 1999), isoenzymes (Segura et al., 2003), amplified fragment length polymorphism (Segura et al., 2002) and random amplified polymorphic DNA (RAPD) (Fajardo et al., 1998; Viana et al., 2003; Junqueira et al., 2007; Bellon et al., 2007, 2009; Cerqueira-Silva et al., 2010).

The application of RAPD markers is not restricted to characterizations related to the Passiflora genus, and consequently, its efficiency in different genetic approaches can be attested to by the recent results obtained through the use of this technique in the solution of problems in different plant species, for example, the characterization of genetic variability among genotypes (Pan et al., 2004; Juchum et al., 2007; Ferrão et al., 2009) and elucidation of the genetic structure of populations (Pham et al., 2009).

In the present study, we quantified, by means of RAPD primers and the complement of the Dice index, the dissimilarity of genotypes originating from wild genotypes of Passiflora trintae Sacco belonging to the active collection of Passiflora of the Universidade Estadual do Sudoeste da Bahia. The results are discussed in terms of characterization and conservation.

\section{MATERIAL AND METHODS}

In the present study, 18 genotypes of Passiflora trintae Sacco (Pt) were evaluated. The genotypes were collected in fragments of jungle-like forest in Vitória da Conquista, Bahia, Brazil (14 $53^{\prime} \mathrm{S}$ and $40^{\circ} 47^{\prime} \mathrm{W}$, altitude of $900 \mathrm{~m}$; average annual precipitation of 700-800 mm, concentrated between November and March, average annual temperature of 20-22 ${ }^{\circ} \mathrm{C}$ ) (Instituto Nacional de Meteorologia/Ministério da Agricultura e Abastecimento), and belonging to the Active Collection of Passiflora Work Germplasm of the Universidade Estadual do Sudoeste da Bahia, Vitória da Conquista Campus (CAGT-Passiflora/UESB 'Planalto de Conquista').

Samples of leaf tissues of all genotypes were collected and stocked in an ultra freezer $\left(-80^{\circ} \mathrm{C}\right)$ until the moment of DNA extraction, according to the protocol of Doyle and Doyle (1990). Amplification reactions carried out using standard procedures described for the RAPD technique were adopted (Williams et al., 1990), and 15 primers from Operon ${ }^{\circ}$ Technologies were used (OPD-01, -02, -05, -07, -11, -12, -13, -18, -20; OPE-01, -02, -03, -07, -09, -11). These primers were previously selected, among 40 primers, because they identified a greater amount of molecular polymorphism of high genetic repeatability (data not showed).

The amplification products were separated by $1.6 \%$ agarose gel electrophoresis, stained with ethidium bromide submerged in $1 \mathrm{X}$ TBE (composed of Tris-borate and EDTA buffer). After electrophoresis, the gels were photographed under ultraviolet light using the photo documentation system EDAS 290 (Kodak). The band pattern observed was used for the construction of a binary data matrix (considering 0 for absence and 1 for presence of bands). Aiming at guaranteeing the reliability of the data, the electrophoretic patterns were evaluated by two researchers and the consensus pattern was considered for the analyses.

Procedures of multivariate statistics were carried out: i) estimation of the complement of genetic similarity $\left(\mathrm{dg}_{\mathrm{ij}}=1-\mathrm{sg}_{\mathrm{ij}}\right.$; where $\mathrm{sg}_{\mathrm{ij}}=$ similarity and $\mathrm{dg}_{\mathrm{ij}}=$ dissimilarity), from the 
Dice coefficient (Dice, 1945); ii) genotype clustering using the unweighted pair group method with arithmetic mean (UPGMA), where this was selected among other hierarchical methods (Ward, Gower, complete linkage, single linkage) since it showed the smallest distortion and stress values, as well as the largest values of cophenetic correlation (Cerqueira-Silva et al., 2009 b); iii) projection of the data on a two-dimensional plane, and iv) evaluation of the quality of the clustering and of the projection on a two-dimensional plane through the estimation of the distortion, stress and correlation values.

The classification proposed by Kruskal (1964) (Table 1) was used for the evaluation of the efficiency of the clustering matrix and the projection of the data on a two-dimensional plane. The statistical analyses were carried out with the assistance of the Genes software, Windows version (Cruz, 2001).

\begin{tabular}{ll}
\multicolumn{2}{|c}{ Table 1. Stress classification for the goodness-of-fit of the graphic projection (Kruskal, 1964). } \\
\hline Stress level (\%) & Goodness-of-fit \\
\hline 40 & Unsatisfactory \\
20 & Regular \\
10 & Good \\
5 & Excellent \\
0 & Perfect \\
\hline
\end{tabular}

\section{RESULTS AND DISCUSSION}

The amplification reactions carried out produced a total number of 112 RAPD bands and an average number of 7.46 bands per primer, with extreme values oscillating from 4 to 12 among the 15 primers used (Table 2). The number of polymorphic bands observed was 94 (84\%), while the number of monomorphic bands observed was $18(16 \%)$. This percentage of polymorphic bands is according to the data available in the literature for characterizations carried out with species of passion fruits through RAPD markers, as with the wild species P. alata (Bellon et al., 2009) and P. nitida (Junqueira et al., 2007), as well as for the cultivated species P. edulis (Bellon et al., 2007; Cerqueira-Silva et al., 2010).

\begin{tabular}{|c|c|c|c|c|}
\hline Primers* & Sequence $5^{\prime} \rightarrow 3^{\prime}$ & No. of polymorphic bands & No. of monomorphic bands & No. of total bands per primer \\
\hline OPD-01 & ACCGCGAAGG & 5 & 1 & 6 \\
\hline OPD-02 & GGACCCAACC & 9 & 1 & 10 \\
\hline OPD-05 & TGAGCGGACA & 7 & 4 & 11 \\
\hline OPD-07 & TTGGCACGGG & 3 & 2 & 5 \\
\hline OPD-11 & AGCGCCATTG & 11 & 0 & 11 \\
\hline OPD-12 & CACCGTATCC & 3 & 1 & 4 \\
\hline OPD-13 & GGGGTGACGA & 4 & 1 & 5 \\
\hline OPD-18 & GAGAGCCAAC & 11 & 0 & 11 \\
\hline OPD-20 & ACCCGGTCAC & 4 & 0 & 4 \\
\hline OPE-01 & CCCAAGGTCC & 8 & 0 & 8 \\
\hline OPE-02 & GGTGCGGGAA & 4 & 2 & 6 \\
\hline OPE-03 & CCAGATGCAC & 5 & 1 & 6 \\
\hline OPE-07 & AGATGCAGCC & 2 & 5 & 7 \\
\hline OPE-09 & CTTCACCCGA & 6 & 0 & 6 \\
\hline OPE-11 & GAGTCTCAGG & 12 & 0 & 12 \\
\hline Total & & 94 & 18 & 112 \\
\hline
\end{tabular}

*Operon Technologies (http://www.operon.com). 
The dissimilarity values obtained by the complement of the Dice index, among the pairs of genotypes of $P$. trintae, showed an average dissimilarity of 0.30 (Table 3 ). The variability values observed among the genotypes of $P$. trintae are similar to other studies of variability in passion fruit. However, unlike the Passiflora spp characterized with molecular markers, there are no records of accessions of $P$. trintae in any of the Passiflora germplasm Brazilian collections consulted by Ferreira (2005). These results indicate that more attention should be given to the search and conservation of the biodiversity of this species. Thus, the characterization of genetic variability among genotypes of $P$. trintae effectively contributes to the identification of pairs of divergent individuals that allow exploring the maximum variability still existing.

\begin{tabular}{|c|c|c|c|c|c|c|c|c|c|c|c|c|c|c|c|c|c|c|}
\hline Genotypes & $-\mathrm{G} 1$ & $-\mathrm{G} 2$ & $-\mathrm{G} 3$ & $-\mathrm{G} 4$ & $-\mathrm{G} 5$ & $-\mathrm{G} 6$ & $-\mathrm{G} 7$ & $-\mathrm{G} 8$ & -G9 & $-\mathrm{G} 10$ & -G11 & $-G 12$ & -G13 & -G14 & $-\mathrm{G} 15$ & $-\mathrm{G} 16$ & -G17 & -G18 \\
\hline Pt-G1 & 0.00 & 0.34 & 0.32 & 0.32 & 0.36 & 0.26 & 0.40 & 0.30 & 0.34 & 0.32 & 0.25 & 0.27 & 0.34 & 0.33 & 0.40 & 0.32 & 0.13 & 0.33 \\
\hline$P t$-G2 & & 0.00 & 0.34 & 0.31 & 0.32 & 0.34 & 0.34 & 0.38 & 0.26 & 0.31 & 0.28 & 0.33 & 0.39 & 0.32 & 0.32 & 0.31 & 0.07 & 0.30 \\
\hline$P t$-G3 & & & 0.00 & 0.38 & 0.32 & 0.35 & 0.37 & 0.28 & 0.34 & 0.40 & 0.29 & 0.30 & 0.43 & 0.38 & 0.34 & 0.36 & 0.09 & 0.31 \\
\hline$P t$-G4 & & & & 0.00 & 0.42 & 0.31 & 0.31 & 0.31 & 0.31 & 0.32 & 0.23 & 0.38 & 0.36 & 0.36 & 0.38 & 0.32 & 0.19 & 0.31 \\
\hline$P t$-G5 & & & & & 0.00 & 0.32 & 0.40 & 0.34 & 0.30 & 0.36 & 0.32 & 0.29 & 0.47 & 0.30 & 0.42 & 0.39 & 0.11 & 0.31 \\
\hline Pt-G6 & & & & & & 0.00 & 0.35 & 0.27 & 0.25 & 0.37 & 0.27 & 0.24 & 0.40 & 0.38 & 0.36 & 0.31 & 0.14 & 0.32 \\
\hline$P t$-G7 & & & & & & & 0.00 & 0.38 & 0.35 & 0.30 & 0.29 & 0.31 & 0.32 & 0.43 & 0.34 & 0.29 & 0.13 & 0.33 \\
\hline Pt-G8 & & & & & & & & 0.00 & 0.24 & 0.33 & 0.26 & 0.25 & 0.35 & 0.35 & 0.42 & 0.34 & 0.13 & 0.23 \\
\hline$P t$-G9 & & & & & & & & & 0.00 & 0.32 & 0.23 & 0.35 & 0.41 & 0.38 & 0.34 & 0.34 & 0.11 & 0.23 \\
\hline$P t$-G10 & & & & & & & & & & 0.00 & 0.26 & 0.38 & 0.34 & 0.39 & 0.46 & 0.40 & 0.10 & 0.22 \\
\hline$P t$-G11 & & & & & & & & & & & 0.00 & 0.19 & 0.28 & 0.23 & 0.28 & 0.27 & 0.11 & 0.16 \\
\hline$P t$-G12 & & & & & & & & & & & & 0.00 & 0.33 & 0.33 & 0.29 & 0.33 & 0.14 & 0.23 \\
\hline$P t$-G13 & & & & & & & & & & & & & 0.00 & 0.39 & 0.38 & 0.37 & 0.13 & 0.24 \\
\hline$P t$-G14 & & & & & & & & & & & & & & 0.00 & 0.41 & 0.39 & 0.15 & 0.34 \\
\hline$P t$-G15 & & & & & & & & & & & & & & & 0.00 & 0.25 & 0.13 & 0.33 \\
\hline$P t$-G16 & & & & & & & & & & & & & & & & 0.00 & 0.10 & 0.34 \\
\hline$P t-\mathrm{G} 17$ & & & & & & & & & & & & & & & & & 0.00 & 0.00 \\
\hline$P t$-G18 & & & & & & & & & & & & & & & & & & 0.00 \\
\hline
\end{tabular}

The molecular characterization of the genetic variability of species contributes both to conservation and potential of establishing breeding phases, allowing: the diagnosis of narrowing of the genetic basis of natural populations and active germplasm banks; the choice of preferential genotypes to be prospected, and the determination of convergent and divergent crossings intra- or interspecifically between wild and commercial genotypes. As far as we know, this is the first record of the estimation of genetic variability for $P$. trintae.

Matrix clustering obtained through the UPGMA showed a percent stress value of $22.3 \%$, a cophenetic correlation coefficient of 0.60 and $5 \%$ distortion (Table 4). In opposition, the projection of distance data on a two-dimensional plane showed a high percent stress value (56.9\%), a low correlation value between the distance matrix and the projection matrix (0.44) and a high distortion percentage (49.8\%). Considering the criterium proposed by Kruskal (1964) (Table 1), the data are inadequate for the projection of distance on a two-dimensional plane. Thus, the visual representation of variability, observed among the genotypes of $P$. trintae, should be carried out using a dendrogram and not dispersion graphs. High percent stress value in the projection of distance in passion fruit has been previously 
Table 4. Efficiency of the clustering matrix and of the projection of distances on a two-dimensional plane, from the diversity observed among Passiflora trintae Sacco genotypes through access of molecular polymorphism by the RAPD technique.

\begin{tabular}{lcr}
\hline & & Method of visualization \\
\cline { 2 - 3 } & Clustering of genotypes & Projection of distance \\
\hline Distortion & $5.00 \%$ & $49.8 \%$ \\
Correlation* & $0.60 \%$ & $0.44 \%$ \\
Stress & $22.3 \%$ & $56.9 \%$ \\
\hline
\end{tabular}

*For the group of genotypes, the coefficient of cophenetic correlation was used. For the projection of distance, the correlation between original distance and two-dimensional plane distance was used.

reported by Cerqueira-Silva et al. (2009b).

The dendrogram obtained by means of the UPGMA method showed a relative distance value varying from zero to 0.34 , but disregarding the genotypes $P t$-G17 and $P t$-G18, the last value being 0.14 (Figure 1). The visual evaluations of the dendrogram allow the identification of homogeneous groups formed by genotypes showing low variability. It is also possible to identify in the dendrogram the groups of genotypes that display the largest intergroup distances.

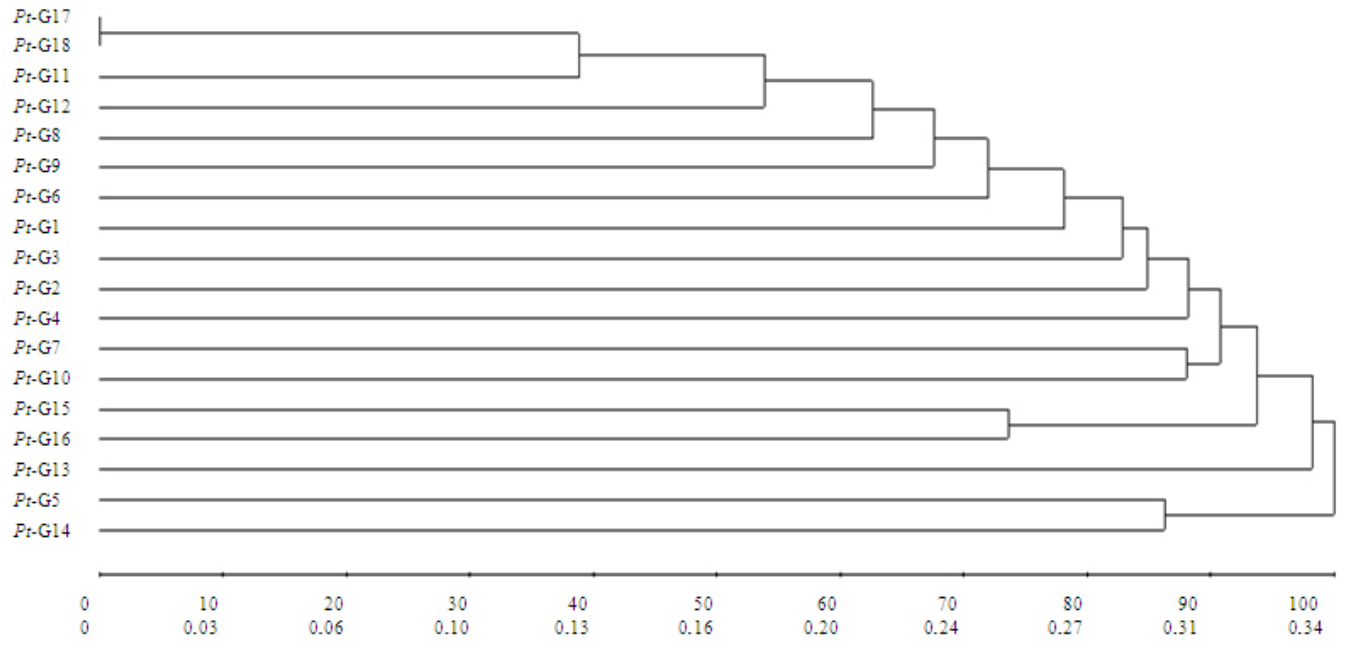

Figure 1. Clustering of 18 Passiflora trintae Sacco genotypes obtained through the clustering method based on unweighted pair group method with arithmetic mean (UPGMA) of distances estimated for the Dice-Sorenso coefficient from RAPD bands. Pt-G1 to Pt-G18 correspond to the evaluated genotypes.

In this context, the increase in accessions in germplasm banks allows both conservation of genetic variability and increment of this variability in breeding programs. With regard to passion fruit plants, the number of species and accessions maintained in work collections and active germplasm banks is considered to be 'modest', both to a national and international extent, to represent the wide variability of the genus (Souza and Meletti, 1997), especially for species such as $P$. trintae that were not represented. The expansion of banks or collections of germplasm, similar to CAGT/Passiflora/UESB 'Planalto de Conquista', based on criteria 
seated in the molecular genetic diversity of almost endemic species (for example, P. trintae), contributes to conservation and use in breeding programs.

The knowledge related to the biological and ecological characteristics, as well as the characterization of the genetic base, are important for conservation and use of species variability.

The species that show reduced distribution and/or are endangered deserve special attention (Juchum et al., 2007), such as P. trintae, which has restricted occurrence, being found in the north of Minas Gerais and in the State of Bahia (Nunes and Queiroz, 2001).

Based on these data, it is indispensable to know the genetic variability of these natural populations, with the aim of selecting individuals with the largest possible intraspecific variability. Besides, the wild species occurring in the Brazilian semi-arid regions may harbor genes for resistance to certain pathogens, which can be of interest in the breeding of the varieties of greater commercial interest.

\section{ACKNOWLEDGMENTS}

Juliane dos Santos Amorim and the biologist Camile Barbosa Moreira contributed during the laboratory phases of the study. We thank CNPq and Programa de Pós-Graduação em Genética e Biologia Molecular of UESC, for allowing the development of this research, which is part of the C.B.M. Cerqueira-Silva Master's dissertation.

\section{REFERENCES}

Bellon G, Faleiro FG, Junqueira KP, Junqueira NTV, et al. (2007). Genetic variability of wild and commercial passion fruit (Passiflora edulis Sims.) accessions using RAPD markers. Rev. Bras. Frutic. 29: 124-127.

Bellon G, Faleiro FG, Peixoto JR, Junqueira KP, et al. (2009). Genetic diversity obtained from cultivated population and native accesses of seewt passion fruit based on RAPD markers. Rev. Bras. Frutic. 31: 197-202.

Bernacci LC (2003). Passifloraceae. In: Flora Fanerogâmica do Estado de São Paulo (Wanderley MGL, Shepherd GJ, Giulietti AM and Melhem TS, eds.). RIMA/FAPESP, São Paulo, 247-248.

Bernacci LC, Meletti LMM, Soares-Scott MD and Passos IRS (2005). Espécies de Maracujá: Caracterização e Conservação da Biodiversidade. In: Maracujá: Germoplasma e Melhoramento Genético (Faleiro FG, Junqueira NTV and Braga MF, eds.). Embrapa Cerrados, Planaltina, 559-586.

Cardoso-Silva CB, Melo JRF, Pereira AS, Cerqueira-Silva CBM, et al. (2007). Study of the genetic diversity of sleeppassion fruit native of Bahia State, Brazil. Magistra 19: 352-358.

Cerqueira-Silva CBM, Cardoso-Silva CB, Nonato JVA, Corrêa RX, et al. (2009a). Genetic dissimilarity of 'yellow' and 'sleep' passion fruit accessions based on the fruits physical-chemical characteristics. Crop Breed. Appl. Biotechnol. 9: $210-218$

Cerqueira-Silva CB, Cardoso-Silva CB, Conceicao LD, Nonato JV, et al. (2009b). Comparison of coefficients and distance measurements in passion fruit plants based on molecular markers and physicochemical descriptors. Genet. Mol. Res. 8: 870-879.

Cerqueira-Silva CBM, Conceição LDHCS, Cardoso-Silva CB, Pereira AS, et al. (2010). Genetic diversity of yellow passion fruit (Passiflora edulis Sims) based on RAPD markers. Crop Breed. Appl. Biotechnol. 10: 154-159.

Cruz CD (2001). Programa Genes: Aplicativo Computacional em Genética e Estatística. Editora Universidade Federal de Viçosa, Viçosa.

Dice LR (1945). Measures of the amount of ecologic association between species. Ecology 26: 297-302.

Doyle JJ and Doyle JL (1990). Isolation of plant DNA from fresh tissue. Focus 12: 13-15.

Fajardo D, Angel F, Grum M, Tohme J, et al. (1998). Genetic variation analysis of the genus Passiflora L. using RAPD markers. Euphytica 101: 341-347.

Faleiro FG, Junqueira NTV and Braga MF (2005). Germoplasma e Melhoramento Genético do Maracujazeiro - Desafios da Pesquisa. In: Maracujá: Germoplasma e Melhoramento Genético (Faleiro FG, Junqueira NTV and Braga MF, eds.). Embrapa Cerrados, Planaltina, 187-210.

Ferrão FAG, Fonseca AFA, Ferrão RG, Barbosa WM, et al. (2009). Genetic divergence in Conilon coffee revealed by 
RAPD markers. Crop Breed. Appl. Biotechnol. 9: 67-74.

Ferreira FR (2005). Recursos Genéticos de Passiflora. In: Maracujá: Germoplasma e Melhoramento Genético (Faleiro FG, Junqueira NTV and Braga MF, eds.). Embrapa Cerrados, Planaltina, 41-50.

Juchum FS, Leal JB, Santos LM, Almeida MP, et al. (2007). Evaluation of genetic diversity in a natural rosewood population (Dalbergia nigra Vell. Allemão ex Benth.) using RAPD markers. Genet. Mol. Res. 6: 543-553.

Junqueira KP, Faleiro FG, Ramos JD, Bellon G, et al. (2007). Genetic variability of wild passion fruit determined by molecular markers. Rev. Bras. Frutic. 29: 571-575.

Kruskal JB (1964). Multidimensional scaling by optimizing goodness of fit to a nonmetric hypothesis. Psychometrika 29: 1-27.

Meletti LMM, Soares-Scot MD, Bernacci LC and Passos IRS (2005). Melhoramento Genético do Maracujá: Passado e Futuro. In: Maracujá: Germoplasma e Melhoramento Genético (Faleiro FG, Junqueira NTV and Braga MF, eds.). Embrapa Cerrados, Planaltina, 55-78.

Nunes TS and Queiroz LP (2001). The family Passifloraceae in the Chapada Diamantina, Bahia, Brazil. Sitientibus Ser. Cienc. Biol. 1: 33-46.

Pan YB, Burner DM, Legendre BL, Grisham MP, et al. (2004). An assessment of the genetic diversity within a collection of Saccharum spontaneum L. with RAPD-PCR. Genet. Resour. Crop Evol. 81: 895-903.

Pham TD, Bui TM, Werlemark G, Bui TC, et al. (2009). A study of genetic diversity of sesame (Sesamum indicum L.) in Vietnam and Cambodia estimated by RAPD markers. Genet. Resour. Crop Evol. 56: 679-690.

Queiroz MA, Nascimento CES, Silva CMM and Lima JLS (1992). Fruteiras Nativas do Semi-Árido do Nordeste Brasileiro: Algumas Reflexões Sobre os Recursos Genéticos. In: Simpósio Nacional de Recursos Genéticos de Fruteiras Nativas.-EMBRAPA-CNPMF, Cruz das Almas, 87-92.

Sánchez I, Angel F, Grum M, Duque MC, et al. (1999). Variability of chloroplast DNA in the genus Passiflora L. Euphytica 106: 15-26.

Segura S, Coppens D’Eeckenbrugge G, Bohorquez A, Ollitrault P, et al. (2002). An AFLP diversity study of the genus Passiflora focusing on subgenus Tacsonia. Genet. Resour. Crop Evol. 49: 111-123.

Segura SD, Coppens D’Eeckenbrugge G, Ocampo CH and Ollitrault P (2003). Isozyme variation in Passiflora subgenera Tacsonia and Manicata. Relationships between cultivated and wild species. Genet. Resour. Crop Evol. 50: 417-427.

Souza JSI and Meletti LMM (1997). Maracujá: Espécies, Variedades, Cultivo. FEALQ, Piracicaba.

Viana AP, Pereira TNS, Pereira MG, Souza MM, et al. (2003). Genetic diversity among yellow passion fruit commercial genotypes and among Passiflora species using RAPD. Rev. Bras. Frutic. 25: 489-493.

Williams JG, Kubelik AR, Livak KJ, Rafalski JA, et al. (1990). DNA polymorphisms amplified by arbitrary primers are useful as genetic markers. Nucleic Acids Res. 18: 6531-6535. 